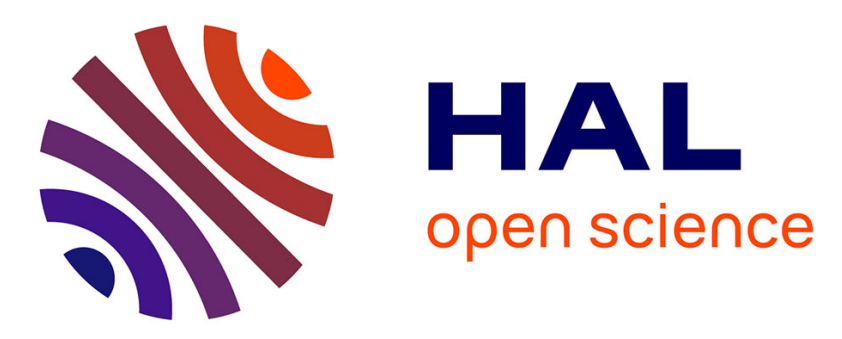

\title{
Effect of initial sulfate level on electron partition between methanogenesis and sulfate reduction in the rumen
}

Y Ohashi, K Ushida, K Miyasaki, Y Kojima

\section{- To cite this version:}

Y Ohashi, K Ushida, K Miyasaki, Y Kojima. Effect of initial sulfate level on electron partition between methanogenesis and sulfate reduction in the rumen. Annales de zootechnie, 1996, 45 (Suppl1), pp.320320. hal-00889642

\section{HAL Id: hal-00889642 https://hal.science/hal-00889642}

Submitted on 1 Jan 1996

HAL is a multi-disciplinary open access archive for the deposit and dissemination of scientific research documents, whether they are published or not. The documents may come from teaching and research institutions in France or abroad, or from public or private research centers.
L'archive ouverte pluridisciplinaire HAL, est destinée au dépôt et à la diffusion de documents scientifiques de niveau recherche, publiés ou non, émanant des établissements d'enseignement et de recherche français ou étrangers, des laboratoires publics ou privés. 


\title{
Effect of initial sulfate level on electron partition between methanogenesis and sulfate reduction in the rumen
}

\author{
Y Ohashi, K Ushida, K Miyasaki, Y Kojima \\ Laboratory of Animal Science, Kyoto Prefectural University, Shimogamo, Sakyo-ku, Kyoto 606, Japan
}

Metabolic hydrogen produced during fermentation is disposed mostly by methanogenesis in the rumen environment. However, sulfate reduction is a potent hydrogen disposal system in anaerobic environments such as sewage sludges and coastal marine sediments. Since sulfate reducers have a higher affinity for hydrogen than do methanogens and the reactions which reduce sulfate have larger free energy changes than methanogenesis, sulfate reducers can anaerobic environment. Our previous study suggested that a low level of free sulfate (less than $1 \mathrm{mM}$ ) was responsible for predominance of methanogen over sulfate reducers in the rumen (Ushida et al, 1995, Deutsche Tieraertzlich Wochenschrift, in press). In this study, we have hypothesized than an appropriate level of free sulfate reducers to out compete the methanogen in the rumen environment. Rumen fluid was sampled from rumen cannulated sheep just before morning feeding. Rumen fluid was squeezed through double layers of gauze and a portion $(2 \mathrm{ml})$ of filtrate was mixed with $0.1 \mathrm{~g}$ substrate (cellulose or starch) and $8 \mathrm{ml}$ of McDougall's buffer containing 5 levels of sulfate. Fermentation was performed in Hungate type tubes for $24 \mathrm{~h}$ at $39^{\circ} \mathrm{C}$. Methane emission and sulfate reduction were quantified. Electron (metabolic hydrogen) partition between methanogenesis and sulfate reduction was estimated as described by Ueki et al (1989, Gen Appl Microbiol, 35, 151-162). Methanogenesis was not inhibited by initial free sulfate levels lower than $20 \mathrm{mM}$. Sulfate reduction was enhanced only at the $20 \mathrm{mM}$ sulfate. However, $90 \%$ of electrons were still utilized in methanogenesis even at the highest level of sulfate. This is distinct from methanogenic sewage sludges in which electron disposal by sulfate reduction out competed methanogenesis at $10 \mathrm{mM}$ sulfate (Ueki et al, 1989). Sulfate reducers appeared not to outcompete methanogens in the rumen even with the higher sulfate supply. The association of methanogens with hydrogenproducing organisms may not be replaceable by sulfate reducers.

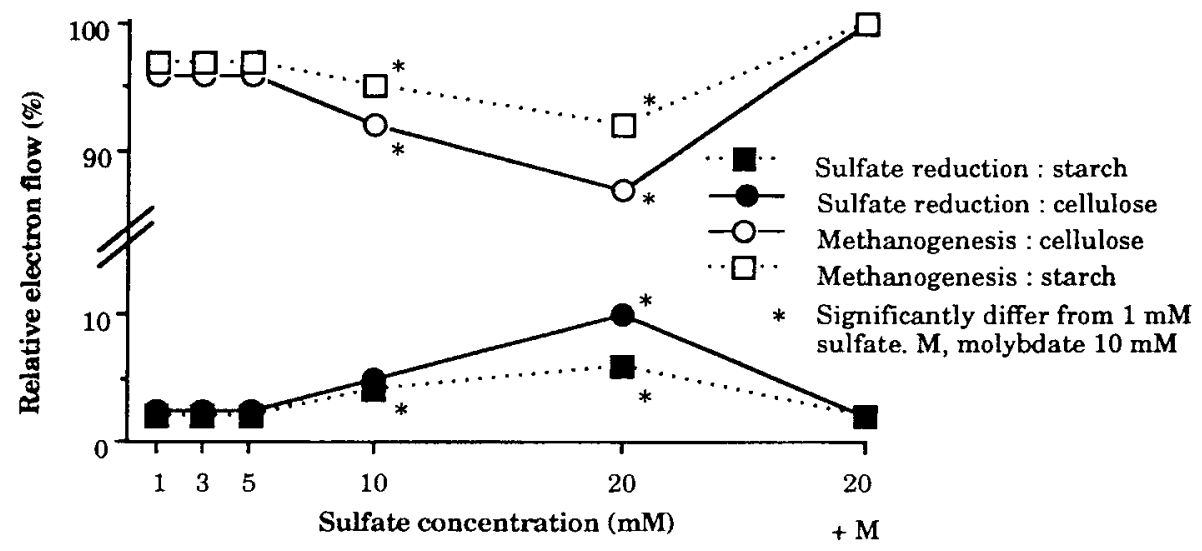

Relative electron flow (\%) in methanogenesis and sulfate reduction 